\title{
Physical Characteristic Changes of Syrian Olive (Olea Europaea) Oils During Irradiation and Storage Time
}

\author{
Mahfouz Al-Bachir \\ Department of Radiation Technology, Atomic Energy Commission of Syria, Damascus, P.O. Box 6091, Syria
}

Correspondence to:

Mahfouz Al-Bachir

Department of Radiation Technology

Atomic Energy Commission of Syria, Damascus

P.O. Box 6091, Syria Arab Republic

Tel: 00963112132580

Fax: 009631161122890

E-mail: ascientific@aec.org.sy

Received: November 24, 2016

Accepted: January 03, 2017

Published: January 06, 2017

Citation: Al-Bachir M. 2017. Physical Characteristic Changes of Syrian Olive (Olea Europaea) Oils During Irradiation and Storage Time. J Food Chem Nanotechnol 3(1): 1-7.

Copyright: (C) 2017 Al-Bachir. This is an Open Access article distributed under the terms of the Creative Commons Attribution 4.0 International License (CC-BY) (http://creativecommons. org/licenses/by/4.0/) which permits commercial use, including reproduction, adaptation, and distribution of the article provided the original author and source are credited.

Published by United Scientific Group

\begin{abstract}
There is no information available in the literature on the effect of gamma irradiation on the physical properties of olive oils. Therefore, the objective of this study was to determine the effect of $\gamma$-irradiation treatment $(0,1,2$ and 3 $\mathrm{kGy}$ ), storage time of olives ( 0,30 and 45 days), and storage time of extracted oils ( 0,6 and 12 months) on physical properties of Syrian Kaissy cv olive oil (SKOO). Refractive index (RI), viscosity and color of olive oils were determined, immediately after extraction and after 6 and 12 months of storage. Results showed that the RI $(1.4659 \pm 0.0002)$, viscosity $\left(151.67 \pm 1.53 \mathrm{mPa} \mathrm{s}^{-1}\right)$, and color parameters (lightness $\left(\mathrm{L}^{*}\right)(71.51 \pm 2.06)$, redness $\left(\mathrm{a}^{*}\right)(14.65 \pm 0.91)$, yellowness $\left(b^{*}\right)(56.85 \pm 3.27)$ and overall color difference $(\Delta \mathrm{E})(53.74 \pm 3.97)$ values of olive oil was significantly $(\mathrm{p}<0.05)$ changed by $\gamma$-irradiation and storage time. In general, the RI of SKOO was significantly $(\mathrm{p}<0.05)$ increased by $\gamma$-irradiation and decreased by extended storage time. The viscosity values of SKOO were significantly $(p<0.05)$ decreased by $\gamma$-irradiation and storage time. Irradiation treatment and storage time increased significantly $(\mathrm{p}<0.05)$ the $\mathrm{a}^{*}$ and $\Delta \mathrm{E}$ values, and decreased significantly $(\mathrm{p}<0.05)$ the $\mathrm{b}^{*}$ of olive oils. The analytical parameters studied of oil extracted from irradiated and non-irradiated fruits were within the limits established by the International Olive Council (IOC, 2015).
\end{abstract}

\section{Keywords}

Olive oil, Viscosity, Refractive index, Color, $\gamma$-irradiation

\section{Introduction}

Olive oil (OO), represents a very popular food commodity, not only for its delicious flavor, but also for its health- promoting potential provided by polyunsaturated fatty acids and other compounds, such as phenolic and oleic acid $[1,2]$. The beneficial health properties of olive oil have been known for centuries, particularly in Mediterranean region [3,4]. A number of studies have already been indicated that the incidence of different types of cancer in the Mediterranean basin is lower compared to other regions [5].

Clear standards and regulars are useful in that they provide the claims with the best feasible oil, diminish the opportunity for fraud, and reward producers who are vigilant in the production of their olive oil [6]. However, both its commercial classification and genuineness evaluation remain legally defined by trade standards compiled in the Codex Alimentarius Norms [7], and the International Olive Council (IOC) Trade Standards [8]. The latter are recognized by most of the olive oil producers and marketers all over the world, since they are drawn up and updated based on IOC olive oil records and databases of the countries that are members of this council, which are the major suppliers of olive oil in the global market [9]. 
Currently, most efforts have focused on understanding the differences in oil quality from olive fruits of different qualities and in the reduction of quality deterioration once the oil is produced [10]. Post-harvest storage of olives has been shown to increase the deterioration of the olive oil [11]. Olive oil quality depends on market preference and is based open consumer perceptions of aroma, taste and color, which may change over time and with location [12].

Irradiation has become an effective means of processing and preserving food products [13]. A Joint FAO/IAEA/WHO Expert Committee on the Wholesomeness of Irradiation of Food has ruled that foods subjected to low dosage (up to $10 \mathrm{kGy}$ ) of irradiation are safe and do not require toxicology testing [14]. The effect of irradiation on locally stored foods is of utmost importance and an insight into these aspects of storage will help in understanding the shelf life of foods as well as its effects on sensitive nutrients [15]. Ionizing radiation has very high energy and leads to some changes in the structure of the organisms and modification of the biological and physiological processes that occur in organ tissues $[13,16,17]$.

Further investigation should be made in post-harvest fruit handling technologies that enhance the generation of positive compound and characteristics. Therefore, the objectives of the present study were to characterize the physical properties of the olive oils produced in Syria, and to determine the effect of $\gamma$-irradiation treatment $(0,1,2$ and $3 \mathrm{kGy})$, storage time of olives ( 0,30 and 45 days), and storage time of extracted oils ( 0 , 6 and 12 months) on physical properties of Syrian Kaissy cv olive oil (SKOO).

\section{Materials and Method}

\section{Material}

Samples of olives of good quality and in the mature firm condition (Kaissy cultivar that the most widespread in Syria) were harvested from the trees grown in grove located at Deer Al Hajar research station, southeast Damascus, Syria (33 21 $\mathrm{N}, 36^{\circ} 28^{\prime} \mathrm{E}$ ) at $617 \mathrm{~m}$ above sea level during $2009 / / 2010$ growing season. Olive fruits were weighed as in the sampling plan and transferred into polyethylene bags for irradiation. The sample size was considered reasonably well enough for the purpose of the study. Each bag of olives $(1 \mathrm{~kg})$ was considered as a replicate.

\section{Treatments and analysis performed}

Olive fruits were irradiated with $0,1,2$ and $3 \mathrm{kGy}$, at room temperature and atmospheric pressure, using as $\gamma$-irradiated ${ }^{60} \mathrm{CO}$ (ROBO, Techsnabexport, Moscow, Russia). The irradiation was carried out in the stationary mode of operation with the possibility of varying dose rate (10.846 to 3.921 $\mathrm{kGy} \mathrm{h}^{-1}$ ) depending on the location and the distance from the source $(10$ to $40 \mathrm{~cm})$. The samples were irradiated at place (15 cm from source) with a dose rate of $9.571 \mathrm{kGy} \mathrm{h}^{-1}$. The absorbed dose was determined using alcoholic chlorobenzene dosimeter [16].

\section{Oil extraction}

The oils from control and irradiated olive fruits were extracted from olives stored at ambient temperature for 0,30 and 45 days after irradiation using a mechanical and physical processes [18]. Olive fruits were crushed with hummer crusher and slowly mixed for about $30 \mathrm{~min}$ at $27{ }^{\circ} \mathrm{C}$, Then, the past mixed was centrifuged at $3000 \mathrm{rpm}$ for $3 \mathrm{~min}$ without addition of water to extract the oil. Finally, the oils were decanted and immediately transferred into dark glass bottles and stored at room temperature $\left(20-25^{\circ} \mathrm{C}\right)$ for the irradiation treatment and physic-chemical properties. Chemical analysis of oils extracted from irradiated and non-irradiated olive fruit samples were performed immediately after irradiation, and after 6 and 12 months of storage.

\section{Chemical and physical analysis of oils}

The refractive index (RI) of olive oil samples was measured in daylight with an Abbe refractometer (VED Carl Zeiss JENA, German) calibrated against pure water at $25^{\circ} \mathrm{C}$. The viscosity of the oils was measured with HAAKE viscometer 6 R plus Model (RTM) using a R2 column at $200 \mathrm{rpm}$. Viscosity values were determined and expressed as $\mathrm{mPa} \mathrm{s}{ }^{-1}$. The color of olive oil was measured using AvaSpec Spectrometer Version 1, 2 June 2003 (Avantes, Holland) and expressed as color L* (lightness), a* (redness), $\mathrm{b}^{*}$ (yellowness) values and overall color difference $(\Delta \mathrm{E})$. Reflectance values were obtained at wave length of $568 \mathrm{~nm}$ by exposing the samples to the illuminant [19]. However, the reported results $\left(L^{*}, a^{*}, b^{*}\right)$ are the mean of 9 determination.

\section{Statistical analysis}

The four treatments were distributed in a completely randomized design with three replicates. Data were subjected to the analysis of variance test (ANOVA) using the SUPERANOVA computer package (Abacus Concepts Inc., Berkeley, CA, USA; 1998). The $p$ value of less than 0.05 was considered statistically. The degree of significance was denoted as: $\mathrm{p}<0.05^{*}, \mathrm{p}<0.01^{* *}[20]$.

\section{Results and Discussion}

\section{Effect of $\gamma$-irradiation and storage period on refractive index of olive oil}

Refractive index (RI) is the measure of the thickness as well as purity or clarity of the oil $[21,22]$. Table 1 , shows the variation of the index of refraction with irradiation dos and storage time of olive oil obtained from Syrian Kaissy cv olive fruits (SKOF) treated at $0,1,2$ and $3 \mathrm{kGy}$ of $\gamma$-irradiation and stored for 0,30 and 45 days before extraction and stored oil at ambient temperature for 0,6 and 12 months after extraction. The initial RI for SKOO obtained from fruits stored at ambient temperature for 0,30 and 45 days were 1.4659 , 1.4640 and 1.4679 , respectively. These values falls within the recommended codex values for olive oils (1.4677-1.4705) [7]. The refractive index of SKOO of 1.4659 showed that it is not as thick as most drying oil whose refractive indices fell between 1.475 and 1.485 [21]. However, significant 
Table 1: Effects of $\gamma$-irradiation and storage period on refractive index $\left(\mathrm{nD} 25^{\circ} \mathrm{C}\right)$ physical properties of olive oil.

\begin{tabular}{|c|c|c|c|c|c|c|}
\hline \multicolumn{2}{|c|}{ Treatments } & Control & $1 \mathrm{KGY}$ & 2 KGY & $3 \mathrm{KGY}$ & P-Value \\
\hline \multicolumn{2}{|c|}{ Storage periods } & Mean \pm SD & Mean \pm SD & Mean \pm SD & Mean \pm SD & \\
\hline \multirow{4}{*}{0 days } & 0 months & $1.466 \pm 0.0002^{\mathrm{aA}}$ & $1.466 \pm 0.0002^{\mathrm{aA}}$ & $1.466 \pm 0.0002^{\mathrm{aA}}$ & $1.466 \pm 0.0002^{\mathrm{aA}}$ & 0.0011 \\
\hline & 6 months & $1.466 \pm 0.0002^{\mathrm{aB}}$ & $1.466 \pm 0.0002^{\mathrm{aB}}$ & $1.457 \pm 0.0002^{\mathrm{aB}}$ & $1.466 \pm 0.0002^{\mathrm{aB}}$ & 0.2192 \\
\hline & 12 months & $1.464 \pm 0.0001^{\mathrm{aC}}$ & $1.464 \pm 0.0001^{\mathrm{aC}}$ & $1.465 \pm 0.0001^{\mathrm{aC}}$ & $1.464 \pm 0.0001^{\mathrm{aA}}$ & 0.0083 \\
\hline & P-Value & 0.0001 & 0.0001 & 0.0001 & 0.0001 & \\
\hline \multirow{4}{*}{30 days } & 0 months & $1.464 \pm 0.0001^{\mathrm{aA}}$ & $1.464 \pm 0.0001^{\mathrm{aA}}$ & $1.464 \pm 0.0001^{\mathrm{aA}}$ & $1.464 \pm 0.0001^{\mathrm{aA}}$ & 0.0001 \\
\hline & 6 months & $1.463 \pm 0.0003^{\mathrm{aB}}$ & $1.463 \pm 0.0003^{\mathrm{aB}}$ & $1.463 \pm 0.0003^{\mathrm{aA}}$ & $1.464 \pm 0.0003^{\mathrm{aB}}$ & 0.0001 \\
\hline & 12 months & $1.462 \pm 0.0001^{\mathrm{aC}}$ & $1.462 \pm 0.0001^{\mathrm{aA}}$ & $1.462 \pm 0.0001^{\mathrm{aA}}$ & $1.462 \pm 0.0001^{\mathrm{aC}}$ & 0.0440 \\
\hline & P-Value & 0.0001 & 0.0001 & 0.0001 & 0.0001 & \\
\hline \multirow{4}{*}{45 days } & 0 months & $1.468 \pm 0.0003^{\mathrm{aA}}$ & $1.467 \pm 0.0003^{\mathrm{aA}}$ & $1.467 \pm 0.0003^{\mathrm{aA}}$ & $1.466 \pm 0.0003^{\mathrm{aA}}$ & 0.0001 \\
\hline & 6 months & $1.467 \pm 0.0001^{\mathrm{aB}}$ & $1.466 \pm 0.0001^{\mathrm{aB}}$ & $1.466 \pm 0.0001^{\mathrm{aB}}$ & $1.466 \pm 0.0001^{\mathrm{aB}}$ & 0.0006 \\
\hline & 12 months & $1.465 \pm 0.0002^{\mathrm{aC}}$ & $1.465 \pm 0.0002^{\mathrm{aC}}$ & $1.466 \pm 0.0002^{\mathrm{aC}}$ & $1.465 \pm 0.0002^{\mathrm{aC}}$ & 0.0113 \\
\hline & P-Value & 0.0001 & 0.0001 & 0.0001 & 0.0001 & \\
\hline
\end{tabular}

abc Means values in the same column not sharing a superscript are significantly different.

${ }_{\mathrm{ABC}}$ Means values in the same row not sharing a superscript are significantly different.

NS: not significant.

* Significant at $\mathrm{p}<0.05$

** Significant at $\mathrm{p}<0.01$.

$\mathrm{N}=3$ replicates for each treatments.

interactions between location, harvest date and crop year were found regarding the characteristics of olive fruits [23]. Results in Table 1 indicate that used doses of $\gamma$-irradiation had a significant $(p<0.01$, except for oil samples extracted from olive immediately after harvest and stored for 6 months) effect in RI of SKOO obtained from olives stored at ambient temperature for 0,30 and 45 days. The RI of all oil samples (extracted from olives stored at ambient temperature for 0,30 and 45 days), and treated with $0,1,2$ and $3 \mathrm{kGy}$ of $\gamma$-irradiation significantly $(\mathrm{p}<0.01)$ dropped during the storage time. All of the samples had RI values between 1.4620 and 1.2679 at $25^{\circ} \mathrm{C}$. It is quite expected a physical constant be within the ranges, as long as there is no purity change the sample [24]. Refractive index of $\gamma$-irradiated groundnut oil were not significantly affected [25]. Dughaish [26] reported that $\gamma$-irradiation caused some change in olive oil structure, which caused the observed change in the physical properties of the oil. From his study he concluded that olive and corn oils were the most sensitive to $\gamma$-irradiation, while sunflower, black seed and palm are less sensitive to $\gamma$-irradiation. The RI value depend on degradation and percentage of polar compounds formed during oxidation and hydrolytic reactions [27]. The refractive value in oils increased due to the unsaturated components formed by $\gamma$-irradiation in oils [26].

Effect of $\gamma$-irradiation and storage period on viscosity of olive oil

Viscosity is a measure of resistance of fluid to deform under shear stress, it commonly perceived as thickness, or resistance to pouring. The absolute viscosity value of the liquid is an important property needed in fluid flow and heat transfer unit operations [28]. The viscosity in term of percent of $\mathrm{mPa} \mathrm{s}^{-1}$ of SKOO obtained from olives treated at $0,1,2$ and $3 \mathrm{kGy}$ of $\gamma$-irradiation and stored at ambient temperature for 0,30 and 45 days before extraction and stored at ambient temperature for 0,6 and 12 months after extraction were presented in Table 2. The initial values of viscosity for SKOO obtained from fruits stored at ambient temperature for 0,30 and 45 days were $151.67,155.00$ and 152.67 , respectively. The viscosity value of SKOO was significantly $(\mathrm{p}<0.05)$ decreased by storage time. The viscosity values of virgin olive oils from three olive varieties growing in Turkey changed between 55.775 and $62.175 \mathrm{mPa} \mathrm{s}^{-1}[29]$.

As shown in Table 2, viscosity of SKOO extracted immediately after the harvesting decreased as the used irradiation doses increased. In fact, the viscosity decreased $(\mathrm{p}<0.01)$ from $151.67 \mathrm{mPa} \mathrm{s}^{-1}$ for control samples to $146.67 \mathrm{mPa}$ $\mathrm{s}^{-1}$ for samples treated with $3 \mathrm{kGy}$. While the viscosity of the SKOO obtained from olives stored at ambient temperature for 30 and 45 days were increased $(\mathrm{p}<0.01)$ as the used irradiation doses increased. The viscosity of the SKOO obtained from olives stored at ambient temperature for 30 days were 155.00 , $157.67,160.00$ and $161.00 \mathrm{mPa} \mathrm{s}^{-1}$, whereas the viscosity of the SKOO obtained from olives stored at ambient temperature for 45 days were $152.67,157.00,157.67$ and $167.00 \mathrm{mPa} \mathrm{s}^{-1}$ for samples treated with $0,1,2$ and $3 \mathrm{kGy}$ respectively. Our results indicate that the difference in the viscosity between irradiated and non-irradiated SKOO may be attributed to the degradation of some high molecular weight components, and changing these components from non-soluble to soluble ones in the test oils. However, $\gamma$-irradiation caused molecular changes resulting destruction the polysaccharides, they would likely be changed of some important properties of the polymers. Lowering the molecular structure of the polysaccharide can be achieved by various methods including ionizing irradiation $[30,31]$. The effect of $\gamma$-irradiation on the viscosity of olive oil 
Table 2: Effects of $\gamma$-irradiation and storage period on viscosity $\left(\mathrm{mPa} \mathrm{s}^{-1}\right)$ refractive of olive oil.

\begin{tabular}{|c|c|c|c|c|c|c|}
\hline \multicolumn{2}{|c|}{ Treatments } & Control & $1 \mathrm{KGY}$ & $2 \mathrm{KGY}$ & $3 \mathrm{KGY}$ & P-Value \\
\hline \multicolumn{2}{|c|}{ Storage periods } & Mean \pm SD & Mean \pm SD & Mean \pm SD & Mean \pm SD & \\
\hline \multirow{4}{*}{0 days } & 0 months & $151.7 \pm 1.5^{\mathrm{aB}}$ & $150.0 \pm 1.7^{\mathrm{abA}}$ & $147.7 \pm 1.5^{\mathrm{bcB}}$ & $146.7 \pm 0.6^{c C}$ & 0.0097 \\
\hline & 6 months & $149.7 \pm 0.6^{\mathrm{aB}}$ & $149.7 \pm 0.6^{\mathrm{aA}}$ & $148.7 \pm 0.6^{\mathrm{abB}}$ & $147.7 \pm 0.6^{\mathrm{bB}}$ & 0.0079 \\
\hline & 12 months & $147.7 \pm 3.4^{\text {aA }}$ & $148.0 \pm 4.7^{\mathrm{A}}$ & $149.7 \pm 1.2^{\mathrm{bA}}$ & $149.0 \pm 0.6^{\mathrm{abA}}$ & 0.1741 \\
\hline & P-Value & 0.0156 & 0.1190 & 0.1866 & 0.0027 & \\
\hline \multirow{4}{*}{30 days } & 0 months & $155.0 \pm 1.0^{\mathrm{cA}}$ & $157.7 \pm 0.6^{6 \mathrm{~A}}$ & $160.0 \pm 1.0^{\mathrm{aA}}$ & $161.0 \pm 0.0^{\mathrm{aA}}$ & 0.0001 \\
\hline & 6 months & $130.0 \pm 0.0^{\mathrm{cC}}$ & $130.7 \pm 0.6^{\mathrm{cC}}$ & $131.7 \pm 0.6^{\mathrm{bC}}$ & $133.0 \pm 0.0^{\mathrm{aC}}$ & 0.0001 \\
\hline & 12 months & $148.0 \pm 1.0^{\mathrm{aB}}$ & $148.0 \pm 1.0^{\mathrm{aB}}$ & $149.0 \pm 1.0^{\mathrm{aB}}$ & $149.3 \pm 0.6^{\mathrm{aB}}$ & 0.2437 \\
\hline & P-Value & 0.0001 & 0.0001 & 0.0001 & 0.0001 & \\
\hline \multirow{4}{*}{45 days } & 0 months & $152.7 \pm 2.5^{\mathrm{cA}}$ & $157.0 \pm 1.0^{\mathrm{bA}}$ & $157.7 \pm 0.6^{6 \mathrm{~A}}$ & $167.0 \pm 0.0^{\mathrm{aA}}$ & 0.0001 \\
\hline & 6 months & $122.3 \pm 0.6^{\mathrm{aB}}$ & $121.3 \pm 0.6^{\mathrm{bC}}$ & $122.0 \pm 0.0^{\mathrm{abC}}$ & $122.7 \pm 0.6^{\mathrm{aC}}$ & 0.0553 \\
\hline & 12 months & $151.3 \pm 0.6^{\mathrm{cA}}$ & $152.0 \pm 0.0^{\mathrm{cB}}$ & $154.7 \pm 1.5^{\mathrm{bB}}$ & $156.7 \pm 0.6^{\mathrm{aB}}$ & 0.0002 \\
\hline & P-Value & 0.0001 & 0.0001 & 0.0001 & 0.0001 & \\
\hline
\end{tabular}

abc Means values in the same column not sharing a superscript are significantly different.

${ }^{A B C}$ Means values in the same row not sharing a superscript are significantly different.

NS: not significant.

* Significant at $\mathrm{p}<0.05$.

* Significant at $\mathrm{p}<0.01$.

$\mathrm{N}=3$ replicates for each treatments.

has not been investigated. Therefore, we compared the results of this study with that performed for other products. Our suggestion is in agreement with those of [32], who reported a dramatic decrease in the dispersion viscosity of heat gelatinized suspension of several irradiated spices with the starch content compared with that of un-irradiated samples. The effect of irradiation seems to be related to the radio-depolymerization of starch in irradiated spices [33]. The previous studies in our lab indicated that, using 5,10,15, and $20 \mathrm{kGy}$ doses of $\gamma$-irradiation decreased the viscosity value of licorice extracts as compared with control samples [17].

Effect of $\gamma$-irradiation and storage period on color parameters of olive oil

The color of olive oil samples was evaluated from the chromatic coordinates $\mathrm{a}^{*}$ corresponding to the green zone, $\mathrm{b}^{*}$ corresponding to the yellow zone, Lightness $\mathrm{L}^{*}$, and $\Delta \mathrm{E}$ values of the absorption spectrum. The color in term of $\mathrm{L}^{*}, \mathrm{a}^{*}$, $\mathrm{b}^{*}$ and $\Delta \mathrm{E}$ values of oils obtained from SKOF treated at $0,1,2$ and $3 \mathrm{kGy}$ of $\gamma$-irradiation and stored at ambient temperature for 0,30 and 45 days before extraction and stored at ambient temperature for 0,6 and 12 months after extraction were presented in Table 3 and 4 .

Lightness $\left(\mathrm{L}^{*}\right)$. As showed in Table 3, the initial $\mathrm{L}^{*}$ values of SKOO obtained from fruits stored at ambient temperature for 0,30 and 45 days were $71.51,50.83$ and 72.24 , respectively. The lightness $\mathrm{L}^{*}$ value of SKOO was significantly $(\mathrm{p}<0.01)$ changed by $\gamma$-irradiation and storage time. Gamma irradiation doses of 1 and $2 \mathrm{kGy}$ decreases significantly $(\mathrm{p}<0.05)$ the $L^{*}$ value of oil obtained from SKOF immediately after harvest. While, 1 and $3 \mathrm{kGy}$ increased significantly $(\mathrm{p}<0.05)$ the $\mathrm{L}^{*}$ value of oil obtained from SKOF stored at ambient temperature for 45 days. However, after 12 months of storage, the $L^{*}$ value of oil extracted from olives immediately after harvest were significantly lower $(p<0.05)$, while the $L^{*}$ value of oil extracted from SKOF stored at ambient temperature for 30 and 45 days were significantly higher $(p<0.05)$ than those of control samples (at month zero of storage).

Redness/greenish $\left(a^{*}\right)$ value. As showed in Table 3, the initial $a^{*}$ values of oil obtained from SKOF stored at ambient temperature for 0,30 and 45 days were $14.65,11.08$ and 24.87, respectively. The greenish a* value of olive oil was significantly $(\mathrm{p}<0.01)$ changed by $\gamma$-irradiation and storage time. In general, $\gamma$-irradiation and storage time increased significantly $(\mathrm{p}<0.05)$ the $\mathrm{a}^{*}$ value of SKOO.

Yellowness ( $b^{*}$ value). As showed in Table 4, the initial $b^{*}$ values of oil obtained from SKOF stored at ambient temperature for 0,30 and 45 days were $56.85,56.24$ and 41.42 , respectively. The yellowness ( $b^{*}$ value) of SKOO was significantly $(\mathrm{p}<0.01)$ changed by $\gamma$-irradiation and storage time. In general, $\gamma$-irradiation and storage time decreased significantly $(p<0.01)$ the $b^{*}$ value of SKOO.

Color difference ( $\Delta \mathrm{E}$ value). As showed in Table 4 , the initial $\Delta \mathrm{E}$ values of oil obtained from SKOF stored at ambient temperature for 0,30 and 45 days were $53.74,66.75$ and 69.43 , respectively. The color difference $(\Delta \mathrm{E}$ value) of $\mathrm{SKOO}$ was significantly $(\mathrm{p}<0.01)$ changed by $\gamma$-irradiation and storage time. In general, $\gamma$-irradiation increased significantly $(p>0.01)$ the $\triangle \mathrm{E}$ of SKOO.

Olive oil color is the results of green and yellow hues due to the presence of color pigments such as chlorophylls and carotenoids. It is influenced by olive cultivar, maturation index, production zone, extraction system, and storage condition. Therefore, the color value is considered as a quality index for its measurement [34].

The used olive oil showed high $\mathrm{a}^{*}$ and $\mathrm{b}^{*}$ values, suggested 


\begin{tabular}{|c|c|c|c|c|c|c|}
\hline Treatments & & Control & $1 \mathrm{KGY}$ & $2 \mathrm{KGY}$ & $3 \mathrm{KGY}$ & P-Value \\
\hline \multicolumn{7}{|c|}{$L$} \\
\hline \multicolumn{2}{|c|}{ Storage periods } & Mean \pm SD & Mean \pm SD & Mean \pm SD & Mean \pm SD & \\
\hline \multirow{4}{*}{0 days } & 0 months & $71.5 \pm 2.1^{\mathrm{aC}}$ & $66.1 \pm 1.3^{\mathrm{bC}}$ & $67.0 \pm 0.2^{\mathrm{bC}}$ & $71.8 \pm 0.4^{\mathrm{aC}}$ & 0.0007 \\
\hline & 6 months & $82.8 \pm 0.1^{\mathrm{aA}}$ & $73.2 \pm 0.3^{\mathrm{bA}}$ & $72.9 \pm 0.1^{\mathrm{bA}}$ & $73.2 \pm 0.1^{\mathrm{bA}}$ & 0.0001 \\
\hline & 12 months & $66.0 \pm 0.4^{\mathrm{cbB}}$ & $68.3 \pm 0.0^{\mathrm{bB}}$ & $65.2 \pm 0.6^{\mathrm{dB}}$ & $69.1 \pm 0.1^{\mathrm{aB}}$ & 0.0001 \\
\hline & P-Value & 0.0001 & 0.0001 & 0.0001 & 0.0001 & \\
\hline \multirow{4}{*}{30 days } & 0 months & $50.8 \pm 0.1^{\mathrm{aC}}$ & $51.8 \pm 0.7^{\mathrm{aC}}$ & $51.5 \pm 1.9^{\mathrm{aC}}$ & $52.0 \pm 0.3^{\mathrm{aC}}$ & 0.5782 \\
\hline & 6 months & $71.4 \pm 0.1^{\mathrm{aA}}$ & $70.6 \pm 0.1^{\mathrm{LB}}$ & $69.8 \pm 0.1^{\mathrm{cB}}$ & $66.8 \pm 0.2^{\mathrm{dB}}$ & 0.0001 \\
\hline & 12 months & $84.9 \pm 0.0^{c B}$ & $85.2 \pm 0.1^{\mathrm{bA}}$ & $84.3 \pm 0.2^{\mathrm{dA}}$ & $93.9 \pm 0.2^{\mathrm{aA}}$ & 0.0001 \\
\hline & P-Value & 0.0001 & 0.0001 & 0.0001 & 0.0001 & \\
\hline \multirow{4}{*}{45 days } & 0 months & $72.2 \pm 0.5^{\mathrm{cC}}$ & $74.7 \pm 0.3^{\mathrm{bA}}$ & $73.6 \pm 1.3^{\mathrm{bcC}}$ & $77.0 \pm 1.0^{\mathrm{aC}}$ & 0.0010 \\
\hline & 6 months & $69.1 \pm 0.1^{\text {Св }}$ & $69.4 \pm 1.4^{\mathrm{bB}}$ & $71.2 \pm 0.0^{\mathrm{aB}}$ & $71.8 \pm 0.6^{\mathrm{aB}}$ & 0.0048 \\
\hline & 12 months & $89.1 \pm 0.6^{\mathrm{bA}}$ & $90.6 \pm 0.5^{\mathrm{aA}}$ & $88.5 \pm 0.9^{\mathrm{bA}}$ & $91.4 \pm 0.1^{\mathrm{aA}}$ & 0.0010 \\
\hline & P-Value & 0.0001 & 0.0001 & 0.0001 & 0.0001 & \\
\hline \multicolumn{7}{|c|}{$\mathbf{a}$} \\
\hline \multirow{4}{*}{0 days } & 0 months & $14.7 \pm 0.9^{\mathrm{bcC}}$ & $12.0 \pm 0.6^{\mathrm{cC}}$ & $17.0 \pm 1.6^{\mathrm{abB}^{\mathrm{bB}}}$ & $17.9 \pm 2.7^{\mathrm{aB}}$ & 0.0097 \\
\hline & 6 months & $29.5 \pm 0.0^{\mathrm{aA}}$ & $28.5 \pm 0.1^{\mathrm{cB}}$ & $28.9 \pm 0.1^{\mathrm{bA}}$ & $29.5 \pm 0.0^{\mathrm{aA}}$ & 0.0001 \\
\hline & 12 months & $25.1 \pm 0.3^{\mathrm{cB}}$ & $27.9 \pm 0.1^{\mathrm{bB}}$ & $28.8 \pm 0.3^{\mathrm{aA}}$ & $28.5 \pm 0.1^{\mathrm{aA}}$ & 0.0001 \\
\hline & P-Value & 0.0001 & 0.0001 & 0.0001 & 0.0002 & \\
\hline \multirow{4}{*}{30 days } & 0 months & $11.1 \pm 0.1^{\mathrm{bC}}$ & $12.5 \pm 0.2^{\mathrm{aA}}$ & $12.3 \pm 0.2^{\mathrm{aC}}$ & $11.4 \pm 0.5^{\mathrm{bC}}$ & 0.0013 \\
\hline & 6 months & $28.3 \pm 0.1^{\mathrm{cB}}$ & $30.5 \pm 0.0^{\mathrm{aB}}$ & $30.1 \pm 0.0^{\mathrm{bB}}$ & $30.0 \pm 0.1^{\mathrm{bB}}$ & 0.0001 \\
\hline & 12 months & $52.1 \pm 1.4^{\mathrm{bA}}$ & $55.5 \pm 0.3^{\mathrm{aA}}$ & $53.7 \pm 0.1^{\mathrm{cA}}$ & $60.3 \pm 0.2^{\mathrm{aA}}$ & 0.0001 \\
\hline & P-Value & 0.0001 & 0.0001 & 0.0001 & 0.0001 & \\
\hline \multirow{4}{*}{45 days } & 0 months & $24.9 \pm 0.3^{\mathrm{bC}}$ & $27.2 \pm 0.2^{\mathrm{aC}}$ & $27.1 \pm 0.4^{\mathrm{aC}}$ & $26.6 \pm 0.9^{\mathrm{aC}}$ & 0.0016 \\
\hline & 6 months & $30.2 \pm 0.1^{\mathrm{cB}}$ & $32.0 \pm 0.1^{\mathrm{bB}}$ & $32.9 \pm 0.1^{\mathrm{aB}}$ & $32.9 . \pm 0.1^{\mathrm{aB}}$ & 0.0001 \\
\hline & 12 months & $57.7 \pm 0.5^{\mathrm{bA}}$ & $59.7 \pm 1.3^{\mathrm{aA}}$ & $56.5 \pm 0.2^{\mathrm{bcA}}$ & $55.2 \pm 0.4^{\mathrm{cA}}$ & 0.0004 \\
\hline & P-Value & 0.0001 & 0.0001 & 0.0001 & 0.0001 & \\
\hline $\begin{array}{l}\text { abc Means values in } \\
\text { ABC } \text { Means values } \\
\text { NS: not significant } \\
{ }^{*} \text { Significant at } p<0 \\
\mathrm{~N}=3 \text { replicates for }\end{array}$ & $\begin{array}{l}\text { me column not } \\
\text { me row not sh }\end{array}$ & $\begin{array}{l}g \text { a superscript } \\
\text { superscript ar }\end{array}$ & $\begin{array}{l}\text { ficantly differe } \\
\text { antly different. }\end{array}$ & & & \\
\hline
\end{tabular}

that the virgin olive oil contain high amount of chlorophyll and carotenoid mass fractions. This is probably the consequence of the harvest at the earlier stage of ripeness. It is known that with increased ripening, the values of these ordinates decrease similarly to those of pigment mass fraction, which is in agreement with the loss of color intensity in the corresponding oils [35].

There is no information available in the literature on the effect of gamma irradiation on the Hunter's color values of olive oils. However, for other plant materials, and in studying the effect of $\gamma$-irradiation treatment on the oil seeds or nuts. Al-Bachir [15] reported that irradiation doses of 1, 2 and 3 $k G y$ had significant effect $(\mathrm{p}<0.05)$ on color values $\left(\mathrm{L}^{*}, \mathrm{a}^{*}\right.$ and $b^{*}$ ) of pistachio oil. Some color change on almond oils due to irradiation was found in almonds oil samples at time zero and after 12 months of storage [36]. Gölge and Ova [37] reported statistically significant change in $L^{*}$ and $b^{*}$ values for pine nuts at doses between 0.5 and $5 \mathrm{kGy}$. Mexis and Kontominas [38] reported a statistically significant change in $\mathrm{a}^{*}$ values for cashew nuts at doses 1.0, 1.5 and $3 \mathrm{kGy}$. Mexis et al. [39] reported a decreased in $L^{*}$ parameter $(p<0.05)$ at dose $>3 \mathrm{kGy}$, while color parameters $\mathrm{a}^{*}$ and $\mathrm{b}^{*}$ remained unaffected after irradiation of almonds kernels at doses up to $7 \mathrm{kGy}$. Irradiation affected the colors of the brush by reducing its brightness and increasing redness and yellowness of the herbal cosmetic products [40]. Irradiation reduced $L^{*}, a^{*}$ and $b^{*}$ values reflecting that the oil became darker or less light. Such darkening in color may be associated with (a) change in properties of proteins through cross linking when they react with hydro-peroxides and their degradation products which is manifested as browning, and (b) non enzymatic lipid-protein interaction causing browning [37]. Cecchi et al. [41] reported that carotenes and chlorophylls contents in virgin olive oil decreased with increasing storage time. 
Table 4: The effects of $\gamma$-irradiation and storage period on color change (b-value (yellowness) and $\Delta \mathrm{E}$ values (overall changes)) of olive oil.

\begin{tabular}{|c|c|c|c|c|c|c|}
\hline Treatments & & Control & $1 \mathrm{KGY}$ & 2 KGY & $3 \mathrm{KGY}$ & P-Value \\
\hline \multicolumn{7}{|c|}{ b } \\
\hline \multicolumn{2}{|c|}{ Storage periods } & Mean \pm SD & Mean \pm SD & Mean \pm SD & Mean \pm SD & \\
\hline \multirow{4}{*}{0 days } & 0 months & $56.9 \pm 3.3^{\mathrm{bA}}$ & $65.7 \pm 2.0^{\mathrm{aA}}$ & $48.3 \pm 3.6^{\mathrm{cA}}$ & $49.0 \pm 5.5^{\mathrm{cA}}$ & 0.0001 \\
\hline & 6 months & $46.5 \pm 0.3^{\mathrm{aB}}$ & $42.7 \pm 0.4^{\mathrm{cB}}$ & $44.4 \pm 0.0^{\mathrm{bA}}$ & $40.9 \pm 0.2^{\mathrm{dB}}$ & 0.0001 \\
\hline & 12 months & $38.7 \pm 0.2^{\mathrm{bC}}$ & $40.4 \pm 0.2^{\mathrm{aB}}$ & $35.2 \pm 0.4^{\mathrm{cB}}$ & $38.7 \pm 0.2^{\mathrm{bB}}$ & 0.0001 \\
\hline & P-Value & 0.0001 & 0.0001 & 0.0006 & 0.0181 & \\
\hline \multirow{4}{*}{30 days } & 0 months & $56.2 \pm 0.2^{\mathrm{aA}}$ & $46.6 \pm 1.7^{\mathrm{cA}}$ & $46.3 \pm 2.7^{\mathrm{cB}}$ & $51.4 \pm 2.3^{\mathrm{bB}}$ & 0.0008 \\
\hline & 6 months & $44.2 \pm 0.2^{\mathrm{aB}}$ & $40.9 \pm 0.5^{\mathrm{dB}}$ & $40.0 \pm 0.0^{\mathrm{cC}}$ & $43.4 \pm 0.2^{\mathrm{dC}}$ & 0.0001 \\
\hline & 12 months & $39.7 \pm 1.4^{\mathrm{cC}}$ & $31.9 \pm 0.5^{\mathrm{dC}}$ & $35.5 \pm 0.5^{\mathrm{bA}}$ & $32.2 \pm 0.1^{\mathrm{aA}}$ & 0.0001 \\
\hline & P-Value & 0.0001 & 0.0001 & 0.0005 & 0.0001 & \\
\hline \multirow{4}{*}{45 days } & 0 months & $41.4 \pm 0.4^{\mathrm{aB}}$ & $35.1 \pm 2.6^{\mathrm{bAB}}$ & $39.2 \pm 1.6^{\mathrm{aA}}$ & $38.4 \pm 1.7^{\mathrm{aB}}$ & 0.0138 \\
\hline & 6 months & $42.7 \pm 0.3^{\mathrm{bA}}$ & $36.4 \pm 0.2^{\mathrm{dA}}$ & $38.7 \pm 0.1^{\mathrm{cA}}$ & $43.7 \pm 0.3^{\mathrm{aA}}$ & 0.0001 \\
\hline & 12 months & $34.8 \pm 0.1^{\mathrm{cC}}$ & $32.3 \pm 2.3^{\mathrm{dB}}$ & $37.8 \pm 0.4^{\mathrm{bA}}$ & $42.4 \pm 0.6^{\mathrm{aA}}$ & 0.0001 \\
\hline & P-Value & 0.0001 & 0.1141 & 0.2711 & 0.0017 & \\
\hline \multicolumn{7}{|c|}{$\Delta \mathrm{E}$} \\
\hline \multirow{4}{*}{0 days } & 0 months & $53.7 \pm 4.0^{\mathrm{bcB}}$ & $49.7 \pm 2.1^{\mathrm{cB}}$ & $63.6 \pm 3.3^{\mathrm{aB}}$ & $61.0 \pm 5.4^{\mathrm{abB}}$ & 0.0078 \\
\hline & 6 months & $64.9 \pm 0.2^{\mathrm{bA}}$ & $65.2 \pm 0.3^{\mathrm{bA}}$ & $63.6 \pm 0.1^{\mathrm{cB}}$ & $67.2 \pm 0.1^{\mathrm{aAB}}$ & 0.0001 \\
\hline & 12 months & $66.4 \pm 0.0^{\mathrm{cA}}$ & $66.2 \pm 0.2^{\mathrm{dA}}$ & $71.1 \pm 0.5^{\mathrm{aA}}$ & $68.1 \pm 0.2^{\mathrm{bA}}$ & 0.0001 \\
\hline & P-Value & 0.0010 & 0.0001 & 0.0049 & 0.0616 & \\
\hline \multirow{4}{*}{30 days } & 0 months & $66.8 \pm 0.2^{\mathrm{cB}}$ & $73.0 \pm 0.8^{\mathrm{a}}$ & $73.5 \pm 0.7^{\mathrm{aA}}$ & $69.3 \pm 1.9^{\mathrm{bB}}$ & 0.0002 \\
\hline & 6 months & $63.4 \pm 0.2^{\mathrm{C}}$ & $67.2 \pm 0.4^{\mathrm{aC}}$ & $67.3 \pm 0.3^{\mathrm{aC}}$ & $64.3 \pm 0.1^{\mathrm{cC}}$ & 0.0001 \\
\hline & 12 months & $67.4 \pm 1.8 \mathrm{~d}^{\mathrm{A}}$ & $74.4 \pm 0.4^{\mathrm{bA}}$ & $70.7 \pm 0.3^{\mathrm{cB}}$ & $81.0 \pm 0.1^{\mathrm{aA}}$ & 0.0001 \\
\hline & P-Value & 0.0066 & 0.0001 & 0.0001 & 0.0001 & \\
\hline \multirow{4}{*}{45 days } & 0 months & $69.4 \pm 0.6^{\mathrm{bB}}$ & $74.8 \pm 2.3^{\mathrm{aB}}$ & $71.7 \pm 1.0^{\mathrm{bB}}$ & $70.9 \pm 2.1^{\mathrm{bA}}$ & 0.0224 \\
\hline & 6 months & $65.3 \pm 0.3^{\mathrm{dC}}$ & $71.8 \pm 0.1^{\mathrm{aB}}$ & $70.4 \pm 0.1^{\text {bB }}$ & $66.1 \pm 0.3^{\mathrm{cB}}$ & 0.0001 \\
\hline & 12 months & $75.9 \pm 0.5^{\mathrm{bA}}$ & $79.2 \pm 2.4^{\mathrm{aA}}$ & $73.1 \pm 0.5^{\mathrm{cA}}$ & $71.0 \pm 0.5^{\mathrm{cA}}$ & 0.0003 \\
\hline & P-Value & 0.0001 & 0.0083 & 0.0067 & 0.0047 & \\
\hline \multicolumn{7}{|c|}{$\begin{array}{l}\text { abc Means values in the same column not sharing a superscript are significantly different. } \\
\text { ABC Means values in the same row not sharing a superscript are significantly different. } \\
\text { NS: not significant. } \\
\text { * Significant at } p<0.05 \text {. }\end{array}$} \\
\hline
\end{tabular}

\section{Conclusion}

Medium doses of $\gamma$-irradiation could be an effect alternative technology in post-harvest pest control because of its ability to kill insects and microorganisms of plant foods $[13,16,17]$. The Syrian Kaissy cv olive oil (SKOO) physical properties including refractive index, viscosity and color parameters appear to be influence by $\gamma$-irradiation treatment $(0,1,2$ and $3 \mathrm{kGy})$, storage time of olive fruits $(0,30$ and 45 days) and storage time of olive oils (0, 6 and 12 months). Further investigations on the effect of irradiation and storage time on physical properties of olive oil using higher doses and other storage conditions should be carried out.

\section{Acknowledgement}

The author wishes to express deep appreciation to the Director General of the Atomic Energy Commission of Syria
(AECS) and the staff of the division of food irradiation.

\section{Author Declaration}

The author reports no conflicts of interest. The author alone is responsible for the content and writing of the manuscript.

\section{References}

1. Waterman E, Lockwood B. 2007. Active components and clinical applications of olive oil. Altern Med Rev 12(4): 331-342.

2. Marongui B, Ozcan MM, Rosa A, Assunta Dessi M, Piras A, et al. 2015. Monitoring of the fatty acid compositions of some olive oils. Rivista Italiana Delle Sostanze Grasse 92(1): 39-42.

3. Dagdelen A, Tümen G, Ozcan MM, Dündar E. 2013. Phenolics profiles of olive fruits (Olea europaea L.) and oils from Ayvalik, Domat and Gemlik varieties at different ripening stages. Food Chem 136(1): 41-45. doi: 10.1016/j.foodchem.2012.07.046

4. Yorulmaz A, Poyrazoglu ES, Ozcan MM, Tekin A. 2012. Phenolic profiles of Turkish olives and olive oils. Eur J Lipid Sci Technol 114(9): 
1083-1093. doi: 10.1002/ejlt.201100186

5. Gotsis E, Anagnosties P, Mariolis A, Vlachou A, Katsiki, N, et al. 2014. Health benefits of the Mediterranean diet: an update of research over last 5 years. Angiology 66(4): 304-318. doi: 10.1177/0003319714532169

6. Mueller T. 2011. Extra virginity: the sublime and scandalous world of olive oil. W.W. Norton \& Company, New York, USA.

7. Codex standard for olive oils and olive pomace oils. Codex Stan 331981 (Rev. 2 - 2003)

8. International Olive Council (IOC). 2015. Trade standard applying to olive oils and olive pomace oil. COI/T.15/NC No 3/Rev.9 June (p. 17)

9. Bajoub A, Hurtado-Fernandez E, Ajal EA, Fernandez-Gutierrez A, Carrasco-Pancorbo A, et al. 2015. Quality and chemical profiles of monovarietal north Moroccan olive oils from "Picholine Marocaine" cultivar: registration database development and geographical discrimination. Food Chem 179: 127-136. doi: 10.1016/j. foodchem.2015.01.101

10. Arslan D, Ozcan MM. 2011. Phenolic profile and antioxidant activity of olive fruits of the Turkish variety "Sariulak" from different locations. Grasas y Aceites 62(4): 453-461. doi: : 10.3989/gya.034311

11. Koprivnjak O, Procida G, Zelinotti T. 2000. Changes in the volatile components of virgin olive oil during fruit storage in aqueous media. Food Chem 70(3): 377-384. doi: 10.1016/S0308-8146(00)00107-2

12. Kalua CM, Allen MS, Bedgood Jr. DR, Bishop AG, Prenzler PD, et al. 2007. Olive oil volatile compounds, flavor development and quality: a critical review. Food Chem 100(1): 273-286. doi: 10.1016/j. foodchem.2005.09.059

13. Al-Bachir M. 2016. Some microbial, chemical and sensorial properties of gamma irradiated sesame (Sesamum indicum L.) seeds. Food Chem 197(Pt A): 191-197. doi: 10.1016/j.foodchem.2015.10.094

14. Wen HW, Chung HP, Chou FI, Lin IH, Hsieh PC. 2006. Effect of gamma irradiation on microbial decontamination, and chemical and sensory characteristic of lyceum fruit. Radiat Phys Chem Oxf Engl 1993 75(5): 596-603. doi: 10.1016/j.radphyschem.2005.12.031

15. AL-Bachir M. 2015. Studies on the physicochemical characteristics of oil extracted from gamma irradiated pistachio (Pistacia vera L.). Food Chem 167: 175-179. doi: 10.1016/j.foodchem.2014.06.020

16. Al-Bachir M. 2004. Effect of gamma irradiation on fungal load, chemical and sensory characteristics of walnuts (Juglans regia L.). J Stored Prod Res 40(4): 355-362. doi: 10.1016/S0022-474X(03)00030-4

17. AL-Bachir M, Lahham G. 2003. The effect of gamma irradiation on the microbial load, mineral concentration and sensory characteristics of licorice (Glycyrrbiza glabra).J Sci Food Agric 83(1): 70-75. doi: 10.1002/jsfa.1276

18. Blatchly RA, Delen Z, O'Hara PB. 2014. Making sense of olive oil: simple experiments to connect sensory observations with the underlying chemistry. J Chem Educ 91(10): 1623-1630. doi: 10.1021/ed300557r

19. Kwon JH, Lee J, Wajea C, Ahn JJ, Kim GR, et al. 2009. The quality of irradiated red ginseng powder following transport from Korea to the United States. Radiat Phys Chem Oxf Engl 1993 78(7-8): 643-646. doi: 10.1016/j.radphyschem.2009.03.055

20. Snedecor G, Cochran W. 1988. Statistical methods. The Iowa State University Press, Ames, Aiwa, pp 221-221.

21. Ogungbenle HN, Afolayan MF. 2015. Physical and chemical characterization of roasted cashew nut (Anacardium occidentale) flour and oil. International Journal of Food Science and Nutrition Engineering 5(1): 1-7. doi: 10.5923/j.food.20150501.0

22. Aydin C, Ozcan MM, Gümüs T. 2009. Nutritional and technological characteristics of olive (Olea europea L.) fruit and oil: two varieties growing in two different locations of Turkey. Int J Food Sci Nutr 60(5): 365-373. doi: 10.1080/09637480701673838

23. Arslan D, Ozcan MM. 2011. Influence of growing area and harvest date on the organic acid composition of olive fruits from Gemlik variety. Sci Hortic 130(3): 633-641. doi: 10.1016/j.scienta.2011.08.020

24. Ogutcu M, Mendes M, Yilmaz E. 2008. Sensorial and physic- chemical characterization of virgin olive oils produced in Canakkale. $\mathrm{IAm}$ Oil Chem Soc 85(5): 441-456. doi: 10.1007/s11746-008-1220-3

25. Nour AAM, Hamed SEA, Osman GAM, Al-Azmi AM. 2009. Effect of gamma irradiation on the physico-chemical characteristics of groundnut (Archis Hypogaea). Aust J Basic E' Appl Sci 3(3): 2856-2860.

26. Dughaish ZH. 2010. Effect of gamma irradiation and heat treatment on some physical properties of vegetable oils. Journal of Natural Science and Mathematics 4(2): 157-170.

27. Benedito J, Garcia-Perez JV, Carmen DM, Mulet A. 2007. Rapid evaluation of frying oil degradation using ultra sonic technology. Food Res Int 40(3): 406-414. doi: 10.1016/j.foodres.2006.10.017

28. Diamante LM, Lan T. 2014. Absolute viscosity of vegetable oils at different temperatures and shear rate of 64.5 to $4835 \mathrm{~s}^{-1}$. Journal of Food Processing 2014: 234583. doi: 10.1155/2014/234583

29. Ozcan MM, Altinoz L, Arslan D, Unver A. 2015. Physical and chemical characteristics of oils of some olive varieties in Turkey. RISG La Rivista Italiana Delle Sostanze Grasse 92(1): 61-68.

30. Byun EH, Kim JH, Sung NY, Choi J, Lim ST, et al. 2008. Effects of gamma irradiation on the physical and structural properties of betaglucan. Radiat Phys Chem OxfEngl 1993 77(6): 781-786. doi: 10.1016/j. radphyschem.2007.12.008

31. Kim JK, Srinivasan P, Kim JH, Choi JI, Park HJ, et al. 2008. Structural and antioxidant properties of gamma irradiation hyaluronic acid. Food Chem 109(4): 763-770. doi: 10.1016/j.foodchem.2008.01.038

32. Farkas J, Koncz A, Sharif M. 1990. Identification of irradiated dry ingredients on the basis of starch damage. Radiat Phys Chem Oxf Engl 1993 35(1-3): 324-338. doi: 10.1016/1359-0197(90)90110-4

33. Gura E, Huckel M, Muller PJ. 199. Specific degradation of hyalurinic acid and its rheological properties. Polym Degrad Stab 59(1-3): 297-302. doi: 10.1016/S0141-3910(97)00194-8

34. Gallardo-Guerrero L, Gandul-Rojas B, Roca M, Mínguez-Mosquera MI. 2005. Effect of storage on the original pigment profile of Spanish virgin olive oil.J Am Oil Chem Soc 82: 33-39. doi: 10.1007/s11746-005-1039-8

35. Poljuha D, Sladonja B, Bubola KB, Radulovic M, Brscic K, et al. 2008. Multidisciplinary approach to the characterization of autochthonous Istrian olive (Olea europaea L.) varieties. Food Technol Biotechnol 46(4): 347-354.

36. AL-Bachir M. 2014. Physicochemical properties of oil extracts from gamma irradiated almond (Prunus amygdalus L.). Innov Rom Food Biotechnol 14: 37-45.

37. Gölge E, Ova G. 2008. The effects of food irradiation on quality of pine nut kernels. Radiat Phys Chem Oxf Engl 1993 77(3): 365-369. doi: 10.1016/j.radphyschem.2007.06.005

38. Mexis SF, Kontominas MG. 2009. Effect of g-irradiation on the physicochemical and sensory properties of cashew nuts (Anacardium occidentale L.). LWT-Food Science and Technology 42(9): 1501-1507. doi: 10.1016/j.lwt.2009.03.023

39. Mexis SF, Badeka AV, Chouliara E, Riganakos KA, Kontominas MG. 2009. Effect of g-irradiation on the physicochemical \& sensory properties of raw unpeeled almond kernels (Prunus dulcis). Innovative Food Science and Emerging Technologies 10(1): 87-92. doi: 10.1016/j. ifset.2008.09.001

40. Neramitmansook N, Chahom M, Prankhogsil P, Phianphak W, Keawchoung P. 2012. Application of gamma irradiation to reduce microbial contamination in herbal cosmetic products. Radiat Phys Chem Oxf Engl 1993 81(8): 1189-1192. doi: 10.1016/j. radphyschem.2011.11.002

41. Cecchi T, Passamonti P, Cecchi P. 2010. Study of the quality of extra virgin olive stored in PET bottles with or without an oxygen scavenger. Food Chem 120(3): 730-735. doi: 10.1016/j.foodchem.2009.11.001 